\title{
An Empirical Analysis on Food Subsidy in India
}

\author{
V.Krishnakumar \\ Assistant Professor, PG and Research Department of Commerce \\ Cardamom Planters Association College, Bodinayakanur, Tamil Nadu, India
}

\section{OPEN ACCESS}

Volume: 7

Issue: 1

Month: July

Year: 2019

ISSN: $2321-788 \mathrm{X}$

Received: 24.06.2019

Accepted: 27.06.2019

Published: 01.07.2019

Citation:

Krishnakumar, V. “An

Empirical Analysis on

Food Subsidy in India.”

Shanlax International

Journal of Arts, Science and Humanities, vol. 7, no. 1, 2019, pp. 123-26.

DOI:

https://doi.org/10.34293/

sijash.v7i1.573

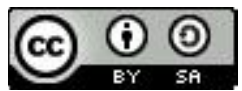

This work is licensed under a Creative Commons Attribution-ShareAlike 4.0 International License

\begin{abstract}
The Public Distribution system is India's largest poverty alleviation programme and it is mainly depends with the subsidy given by the government of India. The subsidy is provided to Food Corporation of India, which is the maininstrument of the Government of India for procurement and distribution of wheatandrice under Targeted Public Distribution System and other welfare schemes and for maintaining the buffer stock of food grains asameasure of food security.This paper makes critical review on the flow of food subsidy given by the Government of India to the Food Corporation of India and how strengthens the poverty alleviation programme by using Government subsidy.

Keywords: Food subsidy, poverty alleviation, food grains, Public Distribution System and food security
\end{abstract}

\section{Introduction}

India is one of the thickly populated countries in the World. Nearly70 percentofits populationis directly orindirectly engagedin agricultural related operations for their livelihood. Ironically, a substantial portion of land holding is vested with a small percentage of people where as there stof the people are doing supporting activities. Further, in India, agricultural activities cannot make much impacton the economic conditions of the people. This is due to number of risks in volve din agriculture. Everincreasing costofinputs, severe drought or excessive rainfall, frequent changes in monsoon resulting in untimelyrainfall, ecological imbalance, larges caleurbanization and uneconomic conditions of cultivablel and force Indian farmers to face continuous crop failures. The conditions of agricultural worker sareal so ever deteriorating. Therefore starvationis a common feature among those who are living in ruralare as. Under this state of affair, a good government has to supply food grains to the poor either at free of costorat a subsidized price. In this regard, the Public Distribution System (PDS) acts as apoverty alleviation programme and contributes towards the social welfare of the people and is the key element of the Government's food security system in India. Itis an instrument for ensuring availability of certaines sential commodities at affordable prices for those who are living below povertyline. The Government, through the Food Corporation of India procures and stocks food grains which are released every month for distribution through the PDS network a cross the country.

\section{Review of the Literature}

- Shah.C.H, (1986) observed that nearly 57 percent of the PDS food grains was for urban areas and only 27 percent for rural areas. In the urban areas as in the rural are as, the poor were not the only beneficiaries, and both the poor and thenon-poor availed of subsidized retail supplies. 
- Jeyalalitha. J (1996) in her assembly speech, "PDS- Government Subsidy Crosses Rs.800 Crores" stated that the public distribution system had been effectively implemented in the state of TamilNadu since most of the beneficiaries were the poor. Sheal so stated that the Government had ordered all the district collectors for proper distribution of essential commodities such asrice, sugar and kerosene to the rural masses in the state. According to her, even though, the central Government had been increasing the price of rice, the Government of TamilNadu did not implement the price hike keeping inmind the welf are of the poor.

- BarbaraHarris (1977) examined the ways in which the state levies on paddy and rice and the associated factor of movementre strictions controlled and distorted the price behavior of "free market" and influenced even the choice of milling technology in TamilNadu. She found that he systemis subsidized neither by the Government, nor the farmers orthe traders; butitis the consumers in the income group not entitled torice under the Public Distribution System whore ally subsidise the system.

- ArvindGupta (1977) examined the policyd evelopment as pectsof the Public Distribution System in the country. He found that the economically vulnerable sections suffered severeerosion in the irrealin comes during 1967 75 which cause dreduction in the irphysical consumption off oodgrains, in spite of the Public Distribution Systems upplies. He brought out the differences in the expected role of the Public Distribution System at the concept uallevel and the actual role at the operational level. It advocated the "direction approach" for protecting the economically vulner able sections under which the Government wills upply the entire needs of the economically vulner able sections at affordable prices. After examining the practicalas pects, hefinally suggested a Public Distribution System coverage of 30 percent of the rural population and 10 percent of the urban population. He, however, did not seriously study the question of Governments ubsidy involved in sucha system.

\section{Statement of the Problem}

While provision of food subsidy is an important element of the food security system in India, an equally important role is played by food procurement and buffer stock operations. The agricultural production is subject to climatic swings and market forces and there is likely to be wide fluctuations in food grain prices. To bring about price stability, it is necessary to build and maintain and adequate level of buffer stock. Therefore, a study related to food subsidy on Public Distribution System is socially relevant and it is inevitable for the largest interest of the society.

\section{Scope of the study}

The present study covers the food subsidy on Public Distribution System for ensures the food security to poor. It does not cover other steps taken by the Government of India for ensure the food security to poor.

\section{Objectives of the Study}

- To reveal the importance of Public Distribution System and food subsidy.

- To analyse the flow of food subsidy for Public Distribution System in India.

- To offer valid suggestion to ensure the food security for poor.

\section{Methodology}

The present study is empirical in nature and it was studied by using secondary data. The secondary data were collected from published and unpublished reports of Food Corporation of India, Books, Journals, Magazines and Websites.

\section{Food Subsidy}

Food subsidy enables in meeting the difference between economic cost of food grainsand their sales realization at Central Issue Prices fixed for Targeted Public Distribution System and other welfare schemes. In addition, the Central Government also procures food grains for meeting there quirements of buffer stock. Hence, apart of the food subsidy also goes towards meeting the carrying cost of buffer stock. 
The subsidy is provided to Food Corporation of India, which is the main instrument of the Government of India for procure mentand distribution of wheat and rice under Targeted Public Distribution System and other welfare schemes and formaintaining the buffer stock of food grains as a measure of food security. In addition, tenstates, namely MadhyaPradesh, Chhattisgarh, West Bengal, Uttarakhand, Tamil Nadu, Andaman and Nicobar, Orissa, Gujarat, Karnataka and Kerala have under taken there sponsibility of not only procuring food grains from within the state but also distributing the same to the targeted population under Targeted Public Distribution System and other welfare schemes. Under this scheme of Decentralized procurement, a state's specific economic cost is determined by the Government of India and the difference between the economic costsis fixed and the Central Issue Pricesis passed on to the state as foods ubsidy. The quantum of foods ubsidy depends on the level of procurement of fo odgrains and off take under Targeted Public Distribution System and other welfare schemes.

To Provide minimum nutritional support to the poor through subsidized food grains and ensure pricestability in different states are the twin objectives of the food security system. But fulfilling the obligation towards ensuring distributive justice, the Government incurs food subsidies.

The following Table 1reveals the food subsidy paid by the Government of India from 2006-07 to 2015-16.
Table 1 Food subsidy paid by the Government of India to the Food Corporation of India from 2006-07 to 2017-18

\begin{tabular}{|c|c|c|c|}
\hline Year & $\begin{array}{c}\text { Subsidy } \\
\text { (Rupees } \\
\text { in Crores) }\end{array}$ & $\begin{array}{c}\text { Increase/ } \\
\text { Decrease }\end{array}$ & $\begin{array}{c}\text { Percentage } \\
\text { Increase/ } \\
\text { Decrease }\end{array}$ \\
\hline $2006-07$ & 20786 & - & - \\
\hline $2007-08$ & 31328 & 10542 & 50.72 \\
\hline $2008-09$ & 43751 & 12423 & 39.65 \\
\hline $2009-10$ & 58443 & 14692 & 33.58 \\
\hline $2010-11$ & 63844 & 5401 & 9.24 \\
\hline $2011-12$ & 72822 & 8978 & 14.06 \\
\hline $2012-13$ & 85000 & 12184 & 16.73 \\
\hline $2013-14$ & 92000 & 7000 & 8.24 \\
\hline $2014-15$ & 117671 & 25671 & 27.90 \\
\hline $2015-16$ & 139419 & 21748 & 18.48 \\
\hline $2016-17$ & 135173 & -4246 & -3.04 \\
\hline $2017-18$ & 145339 & 10166 & 7.52 \\
\hline Source:
\end{tabular}

Source: www.fci.gov.in

It is evident from Table 1 that the food subsidy provided by Government of India to the Food Corporation of India has registered a steady increasing trend, except few years under the study. The food subsidy which stood at Rs.20786 crores in 2006-07 had steadily increased to Rs.145339 crores, in the year 2017-18. It shows that the growth of population and corresponding needs of the food grains of the targeted peoples. Moreover, it is also an evidence of efforts taken by the Government for ensure the food security to poor peoples.

Trend Co-efficient, growth rate and magnitude of variability of growth of Food Subsidy paid by the government to Food Corporation of India, were computed by using semi-loge quation and there sults are presented in Table 2.

Table 2 Trend, Growth and Magnitude of Variability of Food Subsidy

\begin{tabular}{|c|c|c|c|c|c|}
\hline \multirow{2}{*}{ Particulars } & \multicolumn{2}{|r|}{ Semi-log } & \multirow{2}{*}{$\mathbf{R} 2(\%)$} & \multirow{2}{*}{$\begin{array}{c}\text { CGR } \\
\text { (percent/annum) }\end{array}$} & \multirow{2}{*}{$\begin{array}{c}\mathrm{CV} \\
\text { (percent) }\end{array}$} \\
\hline & Constant & Regression Co- efficient & & & \\
\hline Food Subsidy & $8.526(0.097)$ & $0.141 * *(0.010)$ & 0.934 & 38.357 & 62.93 \\
\hline
\end{tabular}

Source: Computed Data

Figures in paren these are standard errors; $* *$ Significant at one percent level.

*Significant at five percent level. CGR - Compound Growth Rate. CV - Co-efficient of Variation.

The results of the analysis in Table 2 reveal that the trendin Food Subsidy paidby the Government to Food Corporation of India was positive and statistically significant at one percent level. It indicates that there is a significant increase in the Food Subsidy paid by the government to Food Corporation of 
Indiaasit's. R2 value is 0.934 . It is also inferred that Food Subsidy paid by the government had increased at therate of 38.357 percent per annum. The analysis also reveals that thereis 62.93 percent variation in the Food Subsidy paid by the government to Food Corporation of India during the study period.

\section{Suggestion and Conclusion}

This paper has examines the flows of subsidy given by Government to Food Corporation of India. The amount of food subsidy depends on a number of factors such as procurement volume, Public Distribution System off take, storage level and efficiency, gap between issue price and procurement, handling efficiency of the various organization and interest charges. In the context of general discussion on reduced food subsidy a number of suggestion have been made. These suggestion directly or indirectly involve one or more of the following measures

- Restrict the volume handled through Public Distribution System by means of effective targeting and reduced leakages.

- Match the procurement, both in terms of commodity composition and volume, with distribution targets so that storage levels can be controlled.

- Increase the efficiency of handling operations, especially the operations of the Food Corporation of India

\section{References}

Gupta, Arvind. Public Distribution of Food Grains in India, Institute of Management, Ahmadabad 1977, pp. 36-42.

Harris, Barbara. "Besieging the Free Market." Green Revolution, edited by B.H. Famer, Macmillan Press, 1977.

Jeyalalitha, J. "PDS-Government Subsidy Crosses Rs.800 Crores", The Tamil Nadu Journal of Co-operation, 1996, pp. 10-14.

Shah. C.H, "Taxation and Subsidies on Agriculture: A Search for Policy Options", Indian Journal of Agricultural Economics, vol. 41, no. 3, 1986, pp. 363-382.

www.dfpd.gov.in

www.fci.gov.in

www.tnpds.gov.in

\section{Author Details}

Dr.V.Krishnakumar, Assistant Professor, $P G$ and Research Department of Commerce

Cardamom Planters Association College, Bodinayakanur, Tamil Nadu, India. Email ID: vkcpac@gmail.com 